Abstracta Iranica Abstracta Iranica

Revue bibliographique pour le domaine irano-aryen

Volume 40-41 | 2019

Comptes rendus des publications de 2017-2018

\title{
Michael Pregill (ed.). Mizan, Journal for the Study of Muslim Societies and Civilizations, New perspectives on late Antique Iran and Irak
}

\section{Florence Somer}

\section{(2) OpenEdition \\ Journals}

Édition électronique

URL : http://journals.openedition.org/abstractairanica/49818

DOI : $10.4000 /$ abstractairanica.49818

ISBN : 1961-960X

ISSN : 1961-960X

Éditeur :

CNRS (UMR 7528 Mondes iraniens et indiens), Éditions de l'IFRI

\section{Référence électronique}

Florence Somer, « Michael Pregill (ed.). Mizan, Journal for the Study of Muslim Societies and Civilizations, New perspectives on late Antique Iran and Irak », Abstracta Iranica [En ligne], Volume 40-41 | 2019, document 12, mis en ligne le 30 décembre 2019, consulté le 21 avril 2021. URL : http://

journals.openedition.org/abstractairanica/49818; DOI : https://doi.org/10.4000/abstractairanica 49818

Ce document a été généré automatiquement le 21 avril 2021.

Tous droits réservés 


\title{
Michael Pregill (ed.). Mizan, Journal for the Study of Muslim Societies and Civilizations, New perspectives on late Antique Iran and Irak
}

\author{
Florence Somer
}

\section{RÉFÉRENCE}

Michael Pregill (ed.). Mizan, Journal for the Study of Muslim Societies and Civilizations, New perspectives on late Antique Iran and Irak, Volume 3, 2018. <http://www.mizanproject.org/ journal-issue/new-perspectives-on-late-antique-iran-and-iraq/>

1 L'ensemble des articles proposés sur le site du projet Mizan pour le troisième volume de 2018 sont dans la continuité de deux conférences données en 2016 visant à mettre en avant la richesse des études interdisciplinaires afin d'appréhender l'héritage scientifique, culturel, politique, économique et linguistique à l'origine de la formation des sociétés dites musulmanes, particulièrement en Iran et en Irak, et de la transmission des savoirs à l'Occident médiéval et pré-moderne. Alors que les sphères gréco-romaines ont été largement étayées, les chercheurs des périodes tardo-antique et médiévales se penchent aujourd'hui sur une étude plus globale en intégrant les données issues d'Afrique, du Moyen-Orient ou de l'Asie centrale. Dans cette perspective, deux articles traitent de la descendance de l'interaction entre l'Iran sassanide, le monde chrétien et les minorités religieuses d'Arabie. Intégrant définitivement l'idée d'une transition politique relativement fluide au moment de la prise de pouvoir des Omeyyades -plutôt que l'irruption d'un régime destructeur et sanglant- deux contributions interrogent la continuité des pouvoirs religieux devenus politiquement minoritaires en Iran et en Irak, principalement les chrétiens et les zoroastriens. Ces contributions relèvent la nécessité de faire appel aux études syriaques, juives et moyen-perses pour comprendre les spécificités culturelles propres 
aux communautés religieuses vivant dans cette aire géographique. La littérature et la poésie préislamiques véhiculent également l'histoire d'une mixité culturelle ou sociale importante et permettent de retracer le fonctionnement d'une tendance antique, largement attestée en Irak comme en Iran, visant à l'assimilation des éléments du passé pour les intégrer puis les utiliser pour construire une nouvelle idiosyncrasie.

\section{AUTEURS}

\section{FLORENCE SOMER}

Doctorante EPHE, Mondes iranien et indien, Paris 